\title{
Pengaruh Konsentrasi Pupuk P Terhadap Tinggi dan Panjang Akar Tagetes erecta L. (Marigold) Terinfeksi Mikoriza Yang Ditanam Secara Hidroponik
}

\author{
Irma Dwi Rahmawati, Kristanti Indah Purwani, dan Anton Muhibuddin \\ Departemen Biologi, Fakultas Ilmu Alam, Institut Teknologi Sepuluh Nopember (ITS) \\ e-mail:kristanti@bio.its.ac.id
}

\begin{abstract}
Abstrak-Mikoriza adalah sistem perakaran yang bersimbiosis mutualisme dengan jamur. Penanaman dengan sistem hidroponik mampu membuat mikoriza melakukan kolonisasi lebih cepat sehingga dapat memaksimalkan penyerapan nutrisi $P$ untuk membantu pertumbuhan tanaman. Penelitian ini untuk mengetahui konsentrasi optimum pemberian pupuk $\mathbf{P}$ cair terhadap pertumbuhan marigold (Tagetes erecta L.) yang telah terinfeksi oleh mikoriza dengan mengukur tinggi tanaman dan panjang akar. Perlakuan yang digunakan adalah dengan memberikan konsentrasi pupuk $P$ (fosfat) cair yang berbedabeda pada tanaman Tagetes erecta yang telah diinfeksikan ke mikoriza dengan beberapa konsentrasi yaitu 0 ppm, 5 ppm, 10 ppm, 20 ppm, 30 ppm dan 40 ppm secara hidroponik. Masingmasing perlakuan diulang sebanyak 4 kali. Hasil analisis ANOVA one-way menunjukkan bahwa adanya pengaruh perlakuan $\mathbf{P}$ cair terhadap pertumbuhan vegetatif tanaman Tagetes erecta. Perlakuan $5 \mathrm{ppm}$ memberikan pengaruh optimum terhadap tinggi tanaman dan panjang akar tanaman.
\end{abstract}

Kata kunci-Hidroponik, mikoriza, pupuk P cair, Tagetes erecta.

\section{PENDAHULUAN}

$\mathrm{H}$ IDROPONIK potensial dalam menghasilkan sistem perakaran yang berasosiasi dengan mikoriza karena dapat menghasilkan propagul yang tinggi sehingga efektif dalam memproduksi inokulum tanpa media tanah. Pertumbuhan mikoriza dihidroponik mampu memberikan hasil yang bagus karena mikoriza dalam hidroponik mampu menyerap nutrisi, melakukan kolonisasi dan memproduksi spora mikoriza dengan lebih cepat.

Dengan cepatnya produksi spora maka mikoriza dan perakaran tanaman lebih efektif. Mikoriza sendiri adalah suatu bentuk hubungan simbiosis mutualisme antara jamur dan perakaran tumbuhan [1]. Jumlah mikoriza sangat melimpah di alam dan ditemukan hampir $80 \%$ dapat bersimbiosis dengan tumbuhan angiospermae [2]. berfungsi untuk mempercepat pertumbuhan dan perkembangan tanaman karena tanaman cukup unsur hara dan air [3]. Mikoriza memiliki korelasi positif dengan aspek sifat fisik, kimia dan biologi [4]. Tanaman yang sebaiknya dijadikan inang mikoriza yaitu seperti karakteristik sebagai berikut (1) tanaman tidak mudah terserang patogen (2) perakaran cepat berkembang sehingga mendukung serapan nutrisi [5]. Hal ini bisa terjadi karena adanya kondisi lingkungan yang mendukung [6]. Yaitu berupa suhu lingkungan, dan $\mathrm{pH}$ [7].
Salah satu tanaman yang bagus dalam inang mikoriza salah satunya Tagetes erecta [8]. Selain mudah tumbuh Tagetes erecta dapat bersimbiosis dengan mikoriza.Tagetes erecta yang ditumbuhkan dalam kondisi hidroponik akan mendukung perkembang biakan mikoriza [9]. Penyerapan hara dalam kondisi hidroponik juga akan lebih baik karena kondisi medium yang mendukung. Sebagai contoh $\mathrm{P}$ yang tidak terikat koloid tanah akan memudahkan diserap tanaman.Berdasarkan hal tersebut maka perlu diadakan penelitian untuk mengetahui konsentrasi optimum pupuk $\mathrm{P}$ cair pada Tagetes erecta terinfeksi mikoriza secara hidroponik.

\section{METODE PENELITIAN}

\section{A. Waktu dan Tempat Penelitian}

Penelitian dilakukan pada bulan Desember 2017 sampai dengan bulan Juni 2018 di Green House Urban Farming Hidroponik Institut Teknologi Sepuluh Nopember yang berlokasi di Jl. Teknik Mesin, Keputih, Sukolilo, Kota Surabaya, Jawa Timur 60117 dan di Laboratorium Biosains dan Teknologi Tumbuhan Departemen Biologi Fakultas Ilmu Alam, Institut Teknologi Sepuluh Nopember (ITS).

\section{B. Alat dan Bahan}

Peralatan yang digunakan untuk penelitian ini yaitu nampan semaian, polybag, autoclave, pipet, gelas obyek, kaca penutup, cawan Petri, sprayer, termometer, oven, neraca analitik, mikroskop, pipa/talang, selang, gelas ukur plastik, pipa pvc, kran air, selotip, lem pvc, TDS meter, bak larutan nutrisi, alat tulis, kamera, penggaris, meteran, ember, jerigen, pengaduk, pompa aquarium.

Bahan-bahan yang digunakan yaitu bibit tanaman Tagetes erecta yang diperoleh dari Bibit Bunga Malang, pupuk mikoriza diperoleh dari Jurusan Hama Penyakit Tanaman Universitas Brawijaya Malang dengan spesies Glomus sp dengan kerapatan spora 21 per gram, tanah taman, air, $\mathrm{KOH}$ $10 \%$, HCL $2 \%$, lactogliserol, gliserol, nutrisi hidroponik AB mix dan pupuk $\mathrm{P}$ (fosfat) cair.

\section{Cara Kerja \\ 1. Tahap Persiapan}

A. Pembuatan sistem Hidroponik NFT

Pipa talang disusun pada alat hidroponik NFT. Konstruksi hidroponik NFT dirancang dengan modifikasi 6 bak larutan 
nutrisi. Bak larutan nutrisi diletakkan sejajar di ujung pipa/talang. Pada sistem NFT menggunakan talang dengan lebar $14 \mathrm{~cm}$ dan panjang $132 \mathrm{~cm}$. Bak nutrisi dapat memanfaatkan box container. Pompa berfungsi untuk mengalirkan larutan nutrisi dari bak nutri ke talang NFT. Kelebaran talang harus memadai agar terhindar dari terbendungnya larutan nutrisi.

\section{B. Persiapan Benih}

Benih tanaman Tagetes erecta yang diperoleh dari Bibit Bunga Malang. Benih akan dilakukan uji viabilitas benih dengan proses perendaman dengan air hangat bersuhu $60^{\circ} \mathrm{C}$ selama 24 jam.

\section{Persiapan Pupuk $P$}

Pupuk cair dalam bentuk senyawa $\mathrm{P}$ didapatkan dari Universitas Brawijaya Malang Fakultas Pertanian.

\section{Persiapan Media Air}

Media air yang digunakan diperoleh dari Kebun Sayur Surabaya, kandungan Nutrisi media air terdiri dari larutan AB. Adapun jenis kandungan nutrisi $\mathrm{AB}$ adalah sebagai berikut $\mathrm{N}-\mathrm{NO}_{3} 160$ ppm, P 30 ppm, K 230 ppm, Ca 100 ppm, Mg 30 ppm, S 60 ppm, Fe 2 ppm, B 0,5 ppm, Mn 0,5 ppm, Zn 0,1 ppm, Cu 0,05 ppm, Mo 0,05 ppm.

\section{E. Persiapan Tanah}

Tanah taman disiapkan sebanyak $5 \mathrm{~kg}$ untuk media penyemaian benih Tagetes erecta. Sampel tanah di sterilisasi dengan uap $121^{\circ} \mathrm{C}$ selama 1 jam atau dengan autoclave kemudian di dinginkan [9].

\section{Tahap Perlakuan}

\section{A. Pembibitan}

Proses pembibitan dilakukan dengan cara semai. Benih disemai ke nampan dengan media tanah steril. Penyemaian dilakukan dengan uji viabilitas benih terlebih dahulu. Viabilitas adalah kemampuan benih atau daya hidup benih untuk tumbuh secara normal pada kondisi optimum. Kondisi optimum adalah kondisi yang sesuai atau mendukung proses perkecambahan [10]. Benih Tagetes erecta yang diperoleh dari Bibit Bunga Malang.

Benih dipelihara di Green House Urban Farming Intitut Teknologi Sepuluh Nopember Surabaya pada suhu $23-30^{\circ} \mathrm{C}$. Sebelum disemai, benih direndam selama 24 jam [11]. Perendaman bertujuan untuk mematahkan masa dormansi benih Tagetes erecta. Hal ini diduga karena proses imbibisi optimal terjadi pada perendaman benih selama 24 jam [9].

\section{B. Pemberian Inokulum Mikoriza}

Inokulum mikoriza yang digunakan berupa inokulum mikoriza spesies Glomus sp dengan jumlah spora 21/gram yang diperoleh dari Jurusan Hama dan Penyakit Tanaman Fakultas Pertanian Universitas Brawijaya Malang. Inokulum mikoriza yang digunakan untuk perlakuan adalah sebanyak 5 gram untuk setiap satu tanaman. Dengan adanya jamur endofit di dalam jaringan tanaman akan memberikan keuntungan bagi tanaman [12]. Penggunaan mikoriza efektif digunakan pada saat tanaman masih di persemaian dimana akarnya belum mengalami penebalan [13]. Hifa mikoriza akan mempermudah penyerapan mikronutient sehingga pertumbuhan akar semakin cepat [14]. Pada kondisi seperti ini peluang mikoriza akan lebih besar untuk menginfeksi akar tanaman [15]. Inokulasi mikoriza dilakukan dengan menggunakan sistem lapisan [16]. Sistem lapisan dari bawah yang dilakukan adalah tanah, pupuk mikoriza, tanah, benih, tanah. Jarak pupuk mikoriza dengan permukaan adalah $2 \mathrm{~cm}$ [9].

Kemudian dilakukan pemilihan tanaman yang sehat dan tidak terjangkit penyakit tanaman. Kondisi lingkungan tanah yang cocok untuk perkecambahan biji akan mendukung pula untuk perkecambahan spora mikoriza [17]. Bagi jamur mikoriza hifa eksternal berfungsi mendukung fungsi reproduksi serta untuk transportasi karbon serta meningkatkan kapasitas dalam penyerapan unsur hara lainnya kedalam spora [18].

Benih yang telah berkembang menjadi satu set daun dan akar ditrasplantasikan secara individu. Tanaman Tagetes erecta yang telah terinfeksi mikoriza selama 3 minggu dimasukkan kedalam rockwool [9]. Tanaman ditumbuhkan didalam green house dengan sistem hidroponik selama 2 bulan.

\section{Pengairan dan Pemupukan}

Sistem pengairan menggunakan sistem hidroponik NFT yang diberi pemupukan nutrisi $\mathrm{P}$ (fosfat) cair yang biasa digunakan untuk nutrisi hidroponik dengan berbagai konsentrasi yaitu 0 ppm, 5 ppm, 10 ppm, 20 ppm, $30 \mathrm{ml}$ dan $40 \mathrm{ppm}$. Satuan $1 \mathrm{ppm}=0,001 \mathrm{ml} / \mathrm{l}$. Pemberian pupuk $\mathrm{P}$ (fosfat) cair dilakukan dengan memberikan konsentrasi sesuai perlakuan kedalam bak nutrisi yang telah disediakan kemudian dialirkan pupuk $\mathrm{P}$ cair menggunakan selang yang telah terhubung dengan bak nutrisi.

Fosfat bagi tanaman berfungsi untuk mempercepat pertumbuhan akar semai, memperkuat batang tubuh tanaman dan mempercepat proses pembuangan, pemasakan buah dan biji-bijian [19]. Pupuk organik cair memiliki banyak kelebihan diantaranya, pupuk tersebut mengandung zat tertentu seperti mikroorganisme jarang terdapat dalam pupuk organik padat dalam bentuk kering [20].

\section{Pengukuran \\ A. Pengamatan Tinggi Tanaman}

Pengukuran pertumbuhan tanaman dilakukan dengan mengukur tinggi batang tanaman Tagetes erecta. Pengukuran tinggi tanaman dilakukan setiap 2 minggu sekali selama 2 bulan saat berada pada sistem hidroponik untuk mengetahui pengaruh fosfor terhadap tinggi Tagetes erecta [21]. Tinggi diukur dari permukaan media sampai pangkal pertumbuhan daun yang paling muda dengan mengukur batang yang paling tinggi [22].

\section{B.Panjang Akar}

Pengamatan panjang akar dilakukan dengan cara membongkar tanaman sampel. Akar diambil dari media kemudian dikering anginkan lalu pengukuran dilakukan setiap mulai pangkal batang sampai ujung akar terpanjang. Pengamatan panjang akar dilakukan setelah tanaman dipanen yaitu setelah 2 bulan masa tanam di media hidroponik.

Kekurangan $\mathrm{P}$ dan $\mathrm{N}$ dapat mempengaruhi pertumbuhan akar [23]. Pada tingkat konsentrasi hara yang rendah, perakaran mengalami defisiensi unsur hara dan menghambat distribusi hara. Defisiensi unsur hara dapat diakibatkan oleh $\mathrm{pH}$ yang cenderung basa. Pada kultur hidroponik $\mathrm{pH}$ yang dianjurkan antara 5-6 agar unsur hara $\mathrm{Cl}$ dapat terserap karena $\mathrm{Cl}$ (Clorin) berperan sebagai aktivator enzim selama produksi oksigen dari air untuk pertumbuhan akar [24]. 


\section{C.Rancangan Penelitian}

Penelitian ini menggunakan Rancangan Acak Lengkap (RAL) dengan perlakuan pupuk $\mathrm{P}$ cair yang terdiri dari 6 level. Perlakuan yang digunakan adalah dengan memberikan dosis pupuk P (fosfat) cair sistem media hidroponik, pada tanaman Tagetes erecta yang telah diinfeksikan ke mikoriza dengan beberapa konsentrasi yaitu 0 ppm, 5 ppm, 10 ppm, 20 ppm, $30 \mathrm{ml}$, dan 40 ppm. Masing-masing perlakuan diulang sebanyak 4 kali.

\section{HASIL DAN DISKUSI}

Pengaruh Konsentrasi Pupuk P Cair Terhadap Pertumbuhan Tagetes erecta L. Terinfeksi Mikoriza Glomus spp Yang di Tanam Secara Hidroponik

\section{Tinggi Tanaman}

Tinggi tanaman Tagetes erecta $\mathrm{L}$. meningkat sejak minggu ke-1 sampai minggu ke-8 namun peningkatan terbesar terjadi pada perlakuan konsentrasi $\mathrm{P}$ cair 40 ppm yang signifikan dibandingkan 0 ppm (kontrol) dan tertinggi dibanding yang lain (Gambar 1). Tinggi tanaman dari minggu ke-7 sampai minggu ke-8 tidak terlalu meningkat drastis.

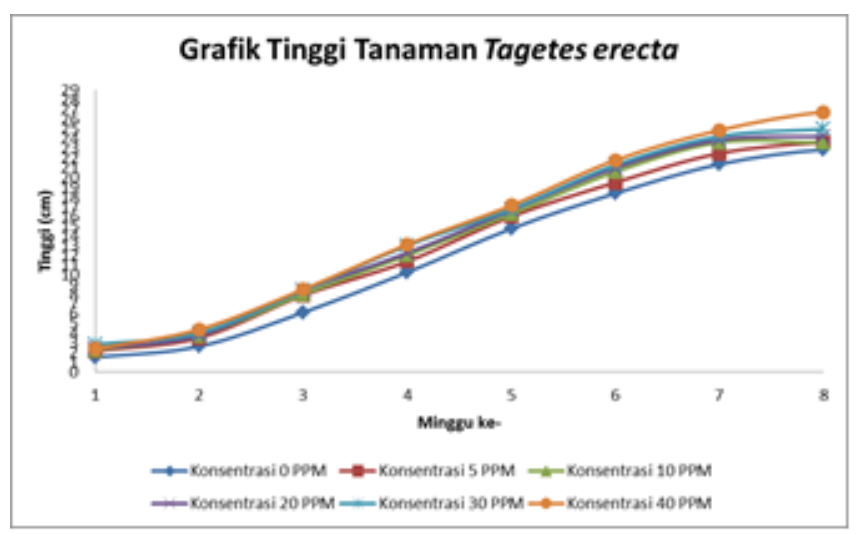

Gambar 1. Grafik Tinggi tanaman Tagetes erecta sampai dengan umur 8 minggu

Tabel 1.

Pengaruh P cair terhadap tinggi tanaman Tagetes erecta Terinfeksi Mikoriza sampai dengan umur 8 minggu $(\mathrm{cm})$

\begin{tabular}{cc}
\hline \hline \multirow{2}{*}{ Perlakuan } & \multicolumn{1}{c}{ Minggu ke- } \\
\cline { 2 - 2 } P1 & $22,88_{\mathrm{a}}$ \\
\hline P2 & $23,88_{\mathrm{b}}$ \\
P3 & $24,13_{\mathrm{b}}$ \\
P4 & $24,5_{\mathrm{b}}$ \\
P5 & \\
P6 & $25,75_{\mathrm{c}}$ \\
\hline \hline
\end{tabular}

Keterangan: Haruf yang berbeda menunjukkan pengaruh berbeda nyata pada kolom dalam uji lanjut Duncan pada selang kepercayaan $95 \%$.

Berdasarkan hasil uji ANOVA tabel 1 menunjukkan bahwa perlakuan penambahan konsentrasi pupuk $\mathrm{P}$ cair pada media tanam berpengaruh terhadap tinggi batang tanaman Tagetes erecta sehingga dilanjutkan uji Duncan yang menunjukkan bahwa penambahan konsentrasi $\mathrm{P}$ cair pada media tanam berpengaruh nyata terhadap tinggi batang tanaman Tagetes erecta. Kerapatan spora mikoriza Glomus spp adalah 21 spora per gram. Glomus memiliki permukaan dinding spora relatif halus [25]. Tinggi tanaman diamati 1 minggu sekali selama 8 minggu. Secara umum pemberian pupuk $\mathrm{P}$ berpengaruh terhadap pertumbuhan tanaman Tagetes erecta dalam media hidroponik. Hal ini terlihat dari peningkatan pertumbuhan Tagetes erecta yang mendapat pupuk $\mathrm{P}$ dibandingkan dengan yang tidak mendapatkan pupuk $P$.

Tinggi tanaman Tagetes erecta pada minggu ke 8 perlakuan $40 \mathrm{ppm}(27 \mathrm{~cm})$ berbeda nyata dengan tinggi tanaman Tagetes erecta perlakuan 0 ppm yang tidak mendapat hara $\mathrm{P}$ tambahan, yaitu $(23 \mathrm{~cm})$. Tinggi tanaman Tagetes erecta pada minggu ke 8 perlakuan 5 ppm $(24 \mathrm{~cm})$ berbeda nyata dengan tinggi tanaman Tagetes erecta perlakuan $0 \mathrm{ppm}$ yang tidak mendapat hara $\mathrm{P}$ tambahan, yaitu $(23 \mathrm{~cm})$. Hasil analisis Duncan, tanaman dengan perlakuan 0 ppm berbeda nyata dengan perlakuan 5 ppm, 10 ppm, 20 ppm, $30 \mathrm{ppm}$ dan $40 \mathrm{ppm}$. Dalam analisis lanjutan menggunakan Duncan konsentrasi 5 ppm berbeda nyata dengan konsentrasi 0 ppm. Perlakuan 5 ppm menunjukkan pertumbuhan optimum yang dapat diberikan. Sehingga, pemberian konsentrasi fosfat 5 ppm signifikan meningkatkan tinggi tanaman dan dapat mengefisiensikan penggunaan pupuk $\mathrm{P}$ dengan menghasilkan pertumbuhan yang optimum.

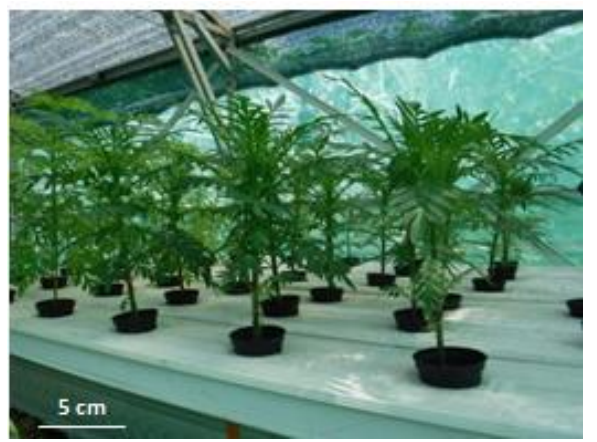

Gambar 2. Tinggi Tanaman Tagetes erecta pada media hidroponik

Tinggi tanaman dipengaruhi oleh faktor unsur hara $\mathrm{P}$. Fosfat $(\mathrm{P})$ dibutuhkan oleh tanaman untuk pembentukan sel baru pada jaringan yang sedang tumbuh serta memperkuat batang [26]. Fosfor adalah nutrisi penting untuk mendukung reproduksi, dan apabila unsur $\mathrm{P}$ mengalami defisiensi maka akan menghambat pembentukan bunga, tongkol, dan mengisi formasi biji-bijian [27]. Berdasarkan penelitian [28] Fosfat dengan konsentrasi 50-120 ppm merupakan kadar optimal yang dapat digunakan untuk perkembangan tanaman. Tinggi tanaman yang signifikan dipengaruhi oleh mikoriza. Dalam penelitian [29] menghasilkan pertumbuhan mikoriza Glomus spp. pada tanaman Acacia mangium dalam sistem kultur hidroponik mengalami peningkatan sebanyak dua kali lebih tinggi dibandingkan dengan yang ditumbuhkan pada media tanah sehingga media hidroponik akan mempermudah $\mathrm{P}$ diserap.

Tanaman yang ditumbuhkan pada kultur hidroponik lebih efisien dalam memanfaatkan unsur hara dan dapat menghasilkan lingkungan aerasi yang tinggi [30]. Hidroponik potensial dalam menghasilkan sistem perakaran yang berasosiasi dengan mikoriza karena dapat menghasilkan propagul yang tinggi sehingga efektif dalam memproduksi inokulum tanpa media tanah. Tanaman Tagetes erecta 
tumbuh baik dan subur mengindikasikan terpenuhinya kebutuhan hara $\mathrm{P}[5]$.

\section{Panjang Akar}

Hasil uji ANOVA pada pengamatan panjang akar tanaman Tagetes erecta menunjukkan bahwa perlakuan penambahan konsentrasi P cair pada media tanam hidroponik berpengaruh terhadap panjang akar tanaman Tagetes erecta sehingga dilakukan uji lanjutan Duncan yang menunjukkan bahwa penambahan konsentrasi $\mathrm{P}$ cair pada media tanam berpengaruh nyata terhadap panjang akar tanaman Tagetes erecta. Berikut merupakan hasil pengamatan berat kering tanaman Tagetes erecta yang telah diuji menggunakan uji Duncan:

Dalam gambar 3 menunjukkan enam jenis konsentrasi yang diberikan mampu meningkatkan panjang akar Tagetes erecta yang dimulai dari konsentrasi $\mathrm{P}$ cair 5 ppm, 10 ppm, $20 \mathrm{ppm}, 30 \mathrm{ppm}$ dan $40 \mathrm{ppm}$ dibandingkan dengan $0 \mathrm{ppm}$ (kontrol). Akar terpanjang diperoleh dengan menggunakan konsentrasi P cair 40 ppm kemudian diikuti konsentrasi 30 ppm. Akar terpendek diperoleh dengan menggunakan perlakuan 0 ppm konsentrasi P cair (Gambar 3).

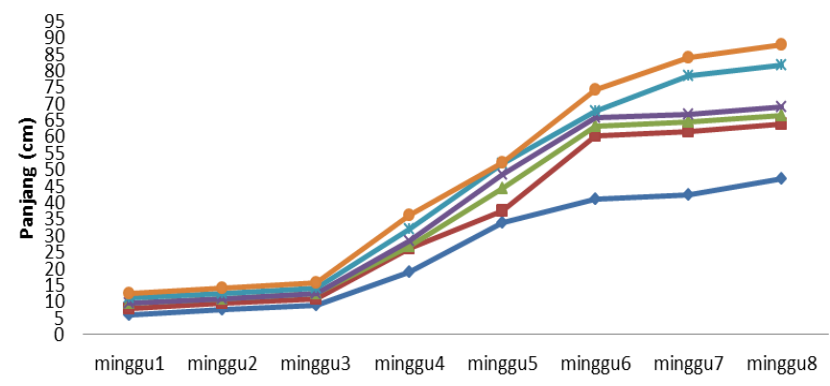
Waktu

$\rightarrow$ Konsentrasi 0 ppm $\rightarrow$ Konsentrasi 5 ppm $\leadsto$ Konsentrasi 10 ppm —Konsentrasi $20 \mathrm{ppm}$ —Konsentrasi $30 \mathrm{ppm} \rightleftharpoons$-Konsentrasi $40 \mathrm{ppm}$

Gambar 3. Grafik Panjang Akar Tagetes erecta sampai dengan umur 8 minggu

Tabel 2.

Pengaruh $\mathrm{P}$ cair terhadap panjang akar tanaman Tagetes erecta Terinfeksi Mikoriza sampai dengan umur 8 minggu $(\mathrm{cm})$

\begin{tabular}{ccccccccc}
\hline \hline \multirow{2}{*}{$\begin{array}{c}\text { Perlaku } \\
\text { an }\end{array}$} & 1 & 2 & 3 & 4 & 5 & 6 & 7 & 8 \\
\cline { 2 - 9 } & $6 \mathrm{a}$ & 7,5 & $9 \mathrm{a}$ & $19 \mathrm{a}$ & $34 \mathrm{a}$ & $41 \mathrm{a}$ & 42,2 & 47,1 \\
$\mathrm{~N} 1$ & & $\mathrm{a}$ & & & & & $5 \mathrm{a}$ & $3 \mathrm{a}$ \\
& $8 \mathrm{~b}$ & 9,5 & $11 \mathrm{~b}$ & 26,2 & 37,3 & 60,3 & 61,6 & 63,7 \\
$\mathrm{P} 2$ & & $\mathrm{~b}$ & & $5 \mathrm{~b}$ & $8 \mathrm{~b}$ & $8 \mathrm{~b}$ & $3 \mathrm{~b}$ & $5 \mathrm{~b}$ \\
& 9,3 & 10, & 12,3 & 26,8 & 44,2 & 63,2 & 64,3 & 66,5 \\
P3 & $8 \mathrm{c}$ & $88 \mathrm{c}$ & $8 \mathrm{c}$ & $8 \mathrm{~b}$ & $5 \mathrm{c}$ & $5 \mathrm{c}$ & $8 \mathrm{c}$ & $\mathrm{c}$ \\
& 9,5 & $11 \mathrm{c}$ & 12,5 & 28,3 & 48,6 & 65,6 & 66,6 & 68,8 \\
P4 & $\mathrm{c}$ & & $\mathrm{c}$ & $8 \mathrm{c}$ & $3 \mathrm{~d}$ & $3 \mathrm{~d}$ & $3 \mathrm{~d}$ & $8 \mathrm{~d}$ \\
& 11, & 12, & 14,1 & 31,8 & 51,8 & 67,8 & 78,3 & 81,7 \\
P5 & 13 & 63 & $3 \mathrm{~d}$ & $8 \mathrm{~d}$ & $8 \mathrm{e}$ & $8 \mathrm{e}$ & $8 \mathrm{e}$ & $5 \mathrm{e}$ \\
& $\mathrm{d}$ & $\mathrm{d}$ & & & & & & \\
& 12, & 14, & 15,6 & 36,1 & 52,1 & 74,1 & 83,8 & 87,8 \\
P6 & $63 \mathrm{e}$ & $13 \mathrm{e}$ & $3 \mathrm{e}$ & $3 \mathrm{e}$ & $3 \mathrm{e}$ & $3 \mathrm{f}$ & $8 \mathrm{f}$ & $8 \mathrm{f}$ \\
\hline \hline
\end{tabular}

Keterangan: Haruf yang berbeda menunjukkan pengaruh berbeda nyata pada kolom dalam uji lanjut Duncan pada selang kepercayaan 95\%.

Pada tabel 2 dapat dilihat dari hasil panjang akar Tagetes erecta bagian tanaman berbanding lurus dengan konsentrasi $\mathrm{P}$ cair yang diberikan. Pada panjang akar perlakuan konsentrasi 0 ppm, 5 ppm, 10 ppm, 20 ppm, 30 ppm dan 40 ppm menunjukkan perbedaan yang berbeda nyata. Hasil uji Duncan menunjukkan bahwa panjang akar Tagetes erecta yang terinfeksi mikoriza mengalami peningkatan pada tanaman yang diberi konsentrasi $\mathrm{P}$ cair 5 ppm sedangkan untuk panjang akar yang paling kecil yaitu saat diberi konsentrasi P cair 0 ppm (kontrol).

Kekurangan $\mathrm{P}$ dapat mempengaruhi pertumbuhan akar. Pada tingkat konsentrasi hara yang rendah, perakaran mengalami defisiensi unsur hara dan menghambat distribusi hara. Defisiensi unsur hara dapat diakibatkan oleh $\mathrm{pH}$ yang cenderung basa. Pada kultur hidroponik $\mathrm{pH}$ yang dianjurkan antara 5-6 agar unsur hara $\mathrm{Cl}$ dapat terserap karena $\mathrm{Cl}$ (Clorin) berperan sebagai aktivator enzim selama produksi oksigen dari air untuk pertumbuhan akar [31].

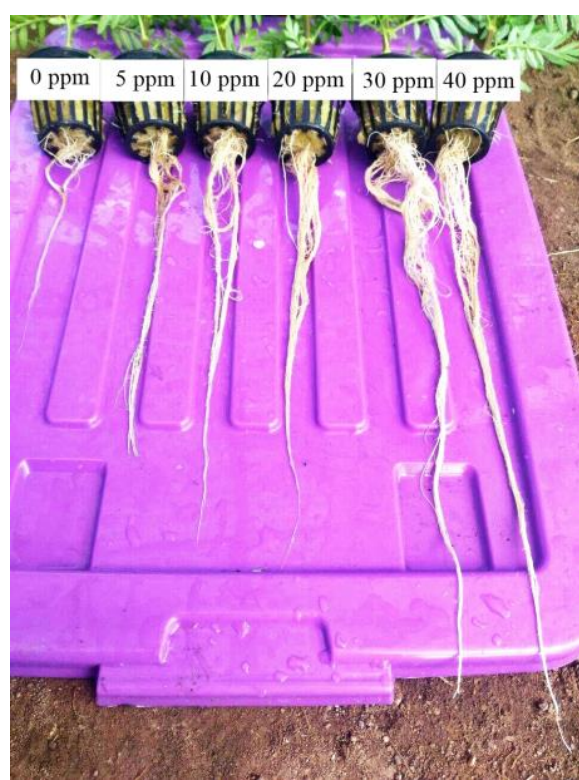

Gambar 4. Panjang akar Tagetes erecta Terinfeksi Mikoriza dalam Media Hidroponik.

Lima jenis konsentrasi yang diberikan mampu meningkatkan panjang akar dibandingkan dengan 0 ppm, hal ini disebabkan karena masing-masing pupuk cair yang diberikan mampu memperbaiki kondisi fisik dan kimia media sehingga akar tumbuh dan berkembang dengan leluasa. Menurut Nurgroho [32] sistem perakaran akan tumbuh maksimal pada kondisi media yang baik secara fisik maupun kimia. Sistem perakaran berkorelasi positif dengan pertumbuhan yang dihasilkan. Semakin panjang akar dari suatu tanaman maka kemampuan tanaman dalam menyerap air dan unsur hara semakin tinggi sehingga akan menghasilkan pertumbuhan yang optimal seperti tinggi tanaman, jumlah tangkai dan jumlah anak daun [33].

Perlakuan terbaik dalam menghasilkan panjang akar diperoleh menggunakan konsentrasi $\mathrm{P}$ cair 5 ppm, hal ini disebabkan karena tanaman Tagetes erecta mendapatkan unsur hara Fosfor yang cukup. Unsur hara yang diserap dalam jumlah cukup akan memacu dan mendorong pemanjangan akar pada bagian pucuk sehingga panjang akar meningkat. Hasil penelitian menunjukkan pemberian konsentrasi pupuk $\mathrm{P}$ cair $5 \mathrm{ppm}$ dalam media hidroponik memberikan peningkatan terhadap panjang akar dibandingkan 0 ppm (kontrol). Konsentrasi yang diberikan pada penelitian ini menghasilkan akar yang semakin panjang. Semakin tinggi konsentrasi yang diberikan maka kadar unsur hara Fosfor yang tersedia di dalam media hidroponik semakin tinggi sehingga banyak unsur hara yang tersedia bagi pertumbuhan akar Tagetes erecta. 


\section{KESIMPULAN}

Berdasarkan peneltian yang telah dilakukan dapat disimpulkan bahwa konsentrasi $\mathrm{P}$ cair 40 ppm merupakan dosis yang paling berpengaruh terhadap pertumbuhan Tagetes erecta pada parameter tinggi tanaman, berat kering tanaman dan panjang akar namun untuk populasi mikoriza dan persentase infeksi mikoriza di dalam akar mengalami penurunan populasi saat berada pada konsentrasi $\mathrm{P}$ cair 40 ppm

\section{DAFTAR PUSTAKA}

[1] R. . Pleger, F.L. and Linderman, "Mycorhizal and plant health," 1996.

[2] A. Cahyani, N.K., Nurhantika, S., Muhibuddin, "Eksplorasi Mikoriza Vesikular Arbuskular (MVA) Indigenous pada Tanah Aluvial di Kabupaten Pamekasan Madura," J. Sains dan Seni POMITS, vol. 3, no. 1, 2014.

[3] I. . Tirta, "Pengaruh Kalium dan Mikoriza Terhadap Pertumbuhan Bibit Panili Vanilla planifolia,” J. Biodiversitas, vol. 7, no. 2, 2006.

[4] S. Syib'li, M.A., Muhibuddin, A., Djauhari, "Arbuscular Mycorrhiza Fungi As An Indicator Of Soil Fertility," J. Agrivita, vol. 35, no. 1, 2013.

[5] D. . Sylvia, "Vesicular-arbuscular mycorrhizal fungi. p," in R.W. Weaver et al. (ed.) Methods of soil analysis, 1994, pp. 351-378.

[6] A. Aliah, N.U., Sulistyowati, L., Muhibuddin, "Hubungan Ketebalan Lapisan Epidermis Daun Terhadap Serangan Jamur (Mycosphaerella Musicola) Penyebab Penyakit Bercak Daun Sigatoka Pada Sepuluh Kultivar Pisang," J. Hpt, vol. 3, no. 1, 2015.

[7] A. Kusumaningati, M.A., Nurhatika, S., Muhibuddin, "Pengaruh Konsentrasi Inokulum Bakteri Zymomonas mobilis Dan Lama Fermentasi Pada Produksi Etanol Dari Sampah Sayur Dan Buah Pasar Wonokromo Surabaya," J. Sains Dan Seni Pomits, vol. 2, no. 2, 2013.

[8] J. . Calvet, C., Pera, J., Barea, "Growth response of marigold (Tagetes erecta L.) to inoculation with Glomus mosseae, Trichoderma aureoviride and Pythium ultimum in a peat-perlite mixture," J. Plant Soil, vol. 148, pp. 1-6, 1993.

[9] R. . Linderman, "Varied Response Of Marigold (Tagetes Spp.) Genotypes To Inoculation With Different Arbuscular Mycorrhizal Fungi," Sci. Hortic. (Amsterdam)., vol. 99, pp. 67-78, 2004.

[10] P. R. Subantoro, R., "Pengaruh Berbagai Metode Pengujian Vigor terhadap Pertumbuhan Benih Kedelai," J. Mediagro, vol. 9, no. 1, pp. 48-60, 2013.

[11] D. . Jones, "Plant and Mycorrhizal Rwgulation of Rhizodeposition," J. New Phytol., vol. 163, no. 3, 2004.

[12] A. Wulandari, D., Sulistyowati, L., Muhibuddin, "Keanekaragaman Jamur Endofit Pada Tanaman Tomat (Lycopersicum esculentum Mill.) Dan Kemampuan Antagonisnya Terhadap Phytophthora infestans," J. HPT, vol. 2, no. 1, 2014.

[13] A. Puspitasari, D., Purwani, K.I., Muhibuddin, "Eksplorasi Vesicular Aruscular Mycorrhiza (VAM) Indigenous pada Lahan Jagung di Desa Torjun, Sampang Madura," J. Sains dan Seni ITS, vol. $1,2012$.

[14] A. Sastrahidayat, I.R., Djauhari, S., Saleh, N., Muhibuddin, "Control Of 'Damping Off' Disease Caused By Sclerotium Rolfsii Sacc. Using Actinomycetes And Vam Fungi On Soybean In The Dry Land Based On Microorganism Diversity Of Rhizosphere Zone," J. Agrivita, vol. 33, no. 1, 2011.

[15] Y. S. Imas, T.R.S. Hadioetomo Dan Gunawan, "Mikrobiologi Tanah II," 1989.

[16] I. Tauchid, "Pengaruh Glomus Aggregatum Yang Diinokulasikan Pada Vetiver (Chrysopogon zizainoides) Dalam Menurunkan Total Petroleum Hydrocarbon," Institut Teknologi Sepuluh Nopember, 2011.

[17] Z. F. \& E. Gani, "Pengaruh inokulasi MVA dan pupuk P terhadap ketersediaan dan serapan P serta hasil tanaman kedelai (Glycine max (L) Merr)," Buletin Agronomi. Univrsitas Jambi, 1996.

[18] Z. Fuady, "Kontribusi Cendawan Mikoriza Arbuskular Terhadap Pembentukan Agregat Tanah Dan Pertumbuhan Tanaman," $J$. Lentera, vol. 13, no. 3, 2013.

[19] S. Sarief, Kesuburan Dan Pemupukan Tanah Pertanian. Bandung: Pustaka Buana, 1993.

[20] S. dan A. Lilia, "Pelatihan Pertanian Organik," Unibraw, Malang, 2003.

[21] S. Saouy, M., Pengchai, P., Choonluchanon, "Development of Arbuskular Mycorrhizal Spore Production in Hydroponic culture on Leaf Lettuce," C. J. Nat. Sci, vol. 10, no. 1, 2011.

[22] I. R. Sastrahidayat, Rekayasa Pupuk Hayati Mikoriza Dalam Meningkatkan Produksi Pertanian. Malang: Universitas Brawijaya Press, 2011.

[23] S. Yoseva, "Pengaruh Pemberian Pupuk Hayati Mikoriza dan Rock Phosphate Terhadap Pertumbuhan dan Produksi Tanaman Jagung Manis (Zea mays saccharata)," in Prosiding Seminar Nasional BKS PTN barat, 2014, pp. 193-200.

[24] B. Subandi, M., Salam, N. P., dan Prasetya, "Pengaruh Berbagai Nilai Conductivity terhadap Pertumbuhan dan Hasil Bayam (Amaranthus sp.) pada Hidroponik Sistem Rakit Apung (Floating Hydroponics System)," J. UIN Sunan Gunung Jati, vol. 9, no. 2 , 2015.

[25] A. Nurhalimah, S., Nurhantika, S., Muhibuddin, "Eksplorasi Mikoriza Vesikular Arbuskular (MVA) indigenous pada Tanah Regosol di Pamekasan, Madura," J. Sains dan Seni POMITS, vol. 3 , no. 1,2014

[26] L. Liferdi, "Efek pemberian fosfor terhadap pertumbuhan dan status hara pada bibit manggis," J. Hortik., vol. 20, no. 1, pp. 18 26, 2010.

[27] A. Astiko, W., Sastrahidayat, I.R., Djauhari, S., Muhibuddin, "The Role of Indigenous Mycorrhiza in Combination with Cattle Manure in Improving Maize Yield (Zea Mays L) on Sandy Loam of Northern Lombok, Eastern of Indonesia," J Trop Soils, vol. 18, no. 1, pp. 53-58, 2013.

[28] J. Raviv, M., Lietch, "Soiless Culture Theory and Pactice," Elseiver, 2008.

[29] F. Martin-Laurent, "A New Approach To Enhance Growth And Nodulation Of Acacia Mangium Through Aeroponic Culture," J. Biol Fertil Soils, vol. 25, pp. 7-12, 1997.

[30] R. . Weathers, P.J., Zobel, "Aeroponics For The Culture Of Organisms, Tissues And Cells," J. Biotec Adv, vol. 10, pp. 93-11, 1992.

[31] B. Subandi, M., Salam, N. P., dan Prasetya, "Pengaruh Berbagai Nilai Conductivity terhadap Pertumbuhan dan Hasil Bayam (Amaranthus sp.) pada Hidroponik Sistem Rakit Apung (Floating Hydroponics System).," J. UIN Sunan Gunung Jati, vol. 9, no. 2, 2015.

[32] N. B, "Petunjuk Penggunaan Pupuk Organik," J. Ilmu Pertan., vol. 13, no. 9, pp. 23-27, 2004.

[33] S. S, Anatomi Tumbuhan. Malang: UM Press, 2004. 